\title{
The Effect of HR Practices on Business Performance in Morocco: An Application of the Universalist
} Approach

\author{
Hayat EL ADRAOUI \\ Morocco, North Africa \\ heladraoui@iscaextra.net
}

\begin{abstract}
The role of HRM in improving business competitiveness is recognized. The scientific literature has several theoretical approaches through which some authors have attempted to validate this hypothesis. The objective of this study is to verify if the companies most successful in Morocco are distinguished by their HR practices under the Universalist approach. We quantitatively analyze the returns of a panel of 92 national and multinational companies in Morocco. A context far unexplored by management researchers. These companies operate, since the $80 \mathrm{~s}$, in a context of strong competition due to the globalization of markets. The results are used to validate the Universalist perspective and argue the scope of certain HR practices in this context.
\end{abstract}

Keywords: HR practices, business performance, Morocco

\section{Introduction}

Investment in the development of HR practices been in recent years a growing interest from the research community. It is becoming increasingly strategic and stands as one of the solutions that allow businesses to be more competitive. Several studies have attempted to validate the alleged relationship between HR practices and business efficiency. Most is done in developed countries, leaving a large validation of this issue in African countries such as Morocco. A context that has been little strategic management studies in the field of Human Resources (SMRH). This paper aims to verify if we can empirically test the hypothesis on the potential impacts of HRM practices on performance in large enterprises in Morocco. In this perspective, we have structured this contribution into five parts: the theoretical framework, the peculiarities of the Moroccan context, methodology and discussion of the results, their managerial implications and limitations.

Theoretical Framework: The HR functions towards arolemoreandmorestrategic. For over twenty years, the scientific literature on the crucial role of HR in maintaining competitive advantage is abundant. Strategic Human Resource Management (SHRM) is characterized by the major interest attributed to the contribution of the HR function in the process of defining and taking strategic decisions. The major concern of the SHRM is to ensure that HRM integrates the needs of the organization (Barrette, Ouellette, 1997). Managers agree a strategic role to HRM at least for two reasons: first, because modern businesses thrive in environments increasingly unstable and then their human resources play an important role in the success of strategies Adaptation (Guerin and Wils, 2002). It shows that HRM taken in its strategic dimension is a vector that is responsible for the success of organizations (Bayad, 1997). To survive, companies are required to develop innovative solutions to stand out from the competition. They have no other options but to act on strategic levers they are able to control. These include financial capital, human and material. Which contributed substantially to the development of the theory of corporate resources (Barney, 1991). Interest in these variables has continued to evolve, which gave birth to the resources that assumes that recent theory can be a competitive advantage of the company if they are generating valuable, rare and difficult to substitute (Christian Arcand and Tellier, 2005). By focusing on the company's internal resources as a source of competitive advantage, this theory considers the staff is not only a success factor in achieving the strategies, but it is the competitive advantage of organizations (Becker, Gerhart, 1996; McMahan, Virich and Wright, 1999; Emery, 2003). HRM has gradually developed from the beginning of industrialization under the influence of several factors related to changes in economic and management requirements of organizations. Administrative HR management is the classic role of the function. It is summed up in an organized information management to help managers make decisions. Its action is courtermiste. Usually in subordination to the financial management given the importance of the payroll (Weiss, 1979; Emery, 2003).

The Performance Concept: The performance concept meanwhile, has undergone many definitions from the management researchers. For a long time, this concept has been reduced to a single dimension focuses on the financial dimension (Bourguignon, 1995). However, the complexity of the economic environment especially 
during the period of the eighties and ninety, has led to a realization that the company's control cannot be limited to one aspect Financial. Thus, given the changes in the competitive environment, there has been an appeal to non-financial performance measures to supplement traditional financial measures. This has accelerated the abandonment of one-dimensional approach to the concept of performance in favor of a multidimensional vision. Furthermore, although the concept of performance is widely developed in the literature, knowledge is still a vague concept and difficult to identify for businesses. The link between HRM practices and performance: a presentation of the Universalist approach HR management, resource theory has formed the basis for the development of strategic management concepts in HR. Around which several theories have developed and tried to study the impact of the development of certain HR practices on performance. The publications of the past 30 years show that the authors agree on the strategic role of HRM in achieving organizational goals (Arcand, 2000; Bayad, 2004).

They demonstrated that whatever the company's size and whatever its strategy and even with the presence of an undeveloped HR function, the company is required to value its staff to be more efficient (Christian Arcand, Tellier and Arcand, 2005). The literature that is chained offers several models that have attempted to explain this link. Some authors Delery and Doty, (1996) in particular, were the first to propose a typology that include these approaches under three names: the Universalist approach, contingency approach and the configurationally approach (Allani-Soltan, Bayad and Arcand, 2004). As part of our study, the Universalist approach is used to validate the RH-performance link in larger companies in Morocco. This approach assumes that certain HR practices have a positive impact wherever it is applied. It was designated by authors like Delery and Doty, (1996) and McMahan, Virick and Wright, (1999) under the title of "best practices" or "one best way". The principle of universalism presumes that certain practices are impervious to organizational contexts and apply whatever its peculiarities. Increase their presence in all cases the probability of greater efficiency (D. Chênevert, B. Sire B., M. Tremblay, 1998). The contingency approach suggests that HR practices to be effective, must beings aligned with organizational factors called contingency and particularly with the business strategy of the organization. Contrary to the principle of the superiority of universalism, the so-called configurationally approach postulates that many HR practices groupings may lead to performance based on the principle of equi-finality.

These configurations are ideal types profiles which organizations must come together to maximize their performance (Allani-Soltan, Bayad and Arcand, 2004). According to this perspective, HR practices should have a synergistic effect between them (internal stowage) in addition to the synergy with the strategy (external stowage) to result in better performance (Lacoursière, Fabi, and ST-Pièrre Arcand, 2004). Other authors such as Barrette, (2005) employ the concepts of horizontal and vertical alignments to describe this synergy. The universality of the theory is not undone theoretical foundations. There are two theoretical foundations on which is based the proponents of this approach (Delery and Doty, 1996; Arcand, 2000). It is based primarily on the human capital theory (Becker, 1962; Schultz, 1961) in that employee skills are considered an asset as the company's other assets, generating wealth if they operate in an appropriate context. And secondly, it is based on the theory of strategic resources (Barney, 1991) in that certain resources in the organization can represent a sustainable competitive advantage if they are rare and difficult to imitate or substitutable. Researchers are still far from unanimous about the superiority of one of three approaches that have been presented (Lacoursière, Fabi, ST-Pièrre and Arcand, 2004). Indeed, this field of research is still perfectible (Arcand, 2000). In Morocco, even less, because we have not had access to studies addressed the relevance of this link.

In the literature, the results seem to support a great extent the principles of the Universalist approach. One of the most cited validations of universalism is that made by Huselid, (1995) of 968 US companies. The measures of the implementation of certain HR practices related to skills development and motivation have been reported in three performance indicators: the level of sales, turnover and growth of shareholder value. Analyzes published by Huselid strongly support the Universalist perspective. Another Canadian study by Barrette and Simeus, (1997) with 36 high-tech companies has validated this approach. Both authors concluded that investment in the practical merit pay appears to significantly influence the level of productivity, profit margin and return on equity prices. As for the evaluation, it influences the growth potential of the shares and the profit margin unlike the practices related to training that explain low extent, the level of productivity of the companies studied.In a survey of 536 employees and managers in Quebec, 
published by Tremblay, Guay and Simard, (2000) the authors examined the perceived influence of four HR processes (dissemination of information, sharing power, skills development and recognition) on organizational commitment and engagement of staff. The study has the feature to test individuals'views in respect of a number of practices rather than HR managers. This realization is confirmed by figures on the evolution of the HR function in Morocco, reported by some law studies.

HR Management Features in Morocco: Several companies still limit the role of the HRF administrative management but external requirements related to the changes that the country lives require the HR function to "equip" (DIORH, 2012) and "professionalize" after some HR questioned. In the Maghreb countries and Morocco in particular by the proximity and similarities of their cultural patterns, issues relating to the development of a model for HRM is of major interest (Frimousse and Peretti, 2005). The challenge faced by many HR professionals in Morocco is approaching advantage of strategic partner and get away from the administrative agent. They concluded that organizational commitment and work behaviors are influenced more by the implementation of HRM practices and how they are perceived by employees, by their presence. The context of the function also reveals another observation related to the gap between multinational and domestic enterprises. The former are often in the implementation of strategies defined at their parent companies. A position that gives them the role of real locomotives contributing to the dissemination of new practices.

HR managers of domestic enterprises meanwhile, face in their daily lives to the difficulty to expand their scope of action to strengthen their contribution. They often lie second in participation in management and in defining strategic orientations. Autonomy in decision making still seems somewhat effective. The HR function in Morocco is in a good momentum of progress despite the silence of Moroccan legislation on some topics such as diversity, ethics and unionism. Under this constraint, some practices are still difficult to implement. Given these factors, we cannot endorse the evolution of HR management practices only to those factors. In order to read the components that have characterized the context in which it evolved (protectorate Moroccanization, border openings, etc.), we offer a substantial overview to see how they are combined to build a modern management of companies. The HR function in Morocco has become necessary with the presence of employees that dates back to early last century with the Protectorate and the introduction of capitalism. Overall we distinguish two periods (1) the period of the protectorate and (2) the period after independence.

The Period of the Protectorate: HRM in Morocco emerged at the beginning of the last century with the colonization and capitalism that brings up the type of employer-employee relationships and that will gradually replace the types of non-wage reporting. Two major events marked the world aware of the 19th century, which led to major changes: the industrial revolution and colonialism. They are closely related since the industrialization of the economy has rapidly created a shortage of raw materials required openings to new markets untouched from exploitation (colonies). Economic growth had become such a strong and legitimate means of conquest that military power. In 1880 Moulay Hassan 1st signed the agreements of the Madrid conference in which twelve Western powers were present. And that was the beginning of the economic protectorate (Ayache, 1957). Between 1919 and 1930, the companions, employers and apprentices were organized into guilds. They received wages and some gifts in kind (Zimmermann, 1914). In 1924, industrial plants have become more numerous and they went to 615 companies employing 7,228 employees. Some of them were as strategic Breweries of Morocco, the company superphosphate and machinery company Schwartz Hautmont (Ayache, 1957). Unionism in Morocco was born with colonialism. Ayache, (1957) argues that the trade union movement in Morocco was an extension of the French labor movement, with all its peculiarities. Over this period, the global economic crisis had affected the traditional economy quickly Moroccans. The peasants were impoverished by the collapse of grain prices and poor harvests and artisans were ruined by the closure of export markets. Among the main wage demands included the recognition of the right, the fight against unemployment, the setting of a minimum wage and application of the law of 08 hours (Ayache, 1957). Under pressure from the strikers, three Royal Decrees were published in the Official Gazette in 1936. Thus was established in Morocco for the first time the principle of the day of 08 hours as it was set in France en 1919. 
Independence Period: After independence, Morocco has tried to restructure its economy. The objective was to develop and protect the emerging economy. During this period, he has expanded that amplified the gap between the two main sectors: the modern sector has inherited a number of activities protectorate employing $30 \%$ of the workforce, and the area which brought together the traditional agriculture and crafts with more than $60 \%$ of the active population (Oved, 1961). The Moroccan State was required to take swift action to put the country on the path of growth. These efforts have focused on three axes (1) the reform of agricultural structures, (2) direct state intervention to increase production and (3) management of the imperatives of Moroccanization services which required a significant investment for training Moroccan executives.

With the swelling of the external debt and pressure from international creditors, the country is launched from the 80s, in a free and open program in the world economy. The result was the adoption of the structural adjustment program in 1983 and continued by the inclusion in the GATT in 1987. At the end of the twentieth century, this commitment is expressed by the conclusion of a number of free trade agreements, first with the European Union in 1996 and the USA in 2004. The objective of these agreements was to free the economic fabric of the heavy state intervention. Faced with the demands of increasingly strong, companies were required to mobilize their employees around these challenges. Modern management has begun to develop productivity-enhancing and consideration of the wealth of human capital.

\section{Empirical Work}

Our empirical work is not just about large national enterprises, otherwise we would have provided limited lighting a part of reality to answer our questions. For this, our investigation also includes multinationals operating in Morocco. In total we interviewed 92 companies among the top performers. In the following we present the hypothesis and research model, a description of the main characteristics of the firms in our sample and the results obtained from the correlation analyzes. Chat conclusion will highlight the limitations, managerial implications and possible extensions of our contribution.

The Model and the Hypothesis of the Research: Based on the contributions of the literature, we present the following Universalist hypothesis and research model for it:

Hypothesis: "Some HRM practices have a positive effect on business performance in Morocco

Figure 1: Reasearch Model

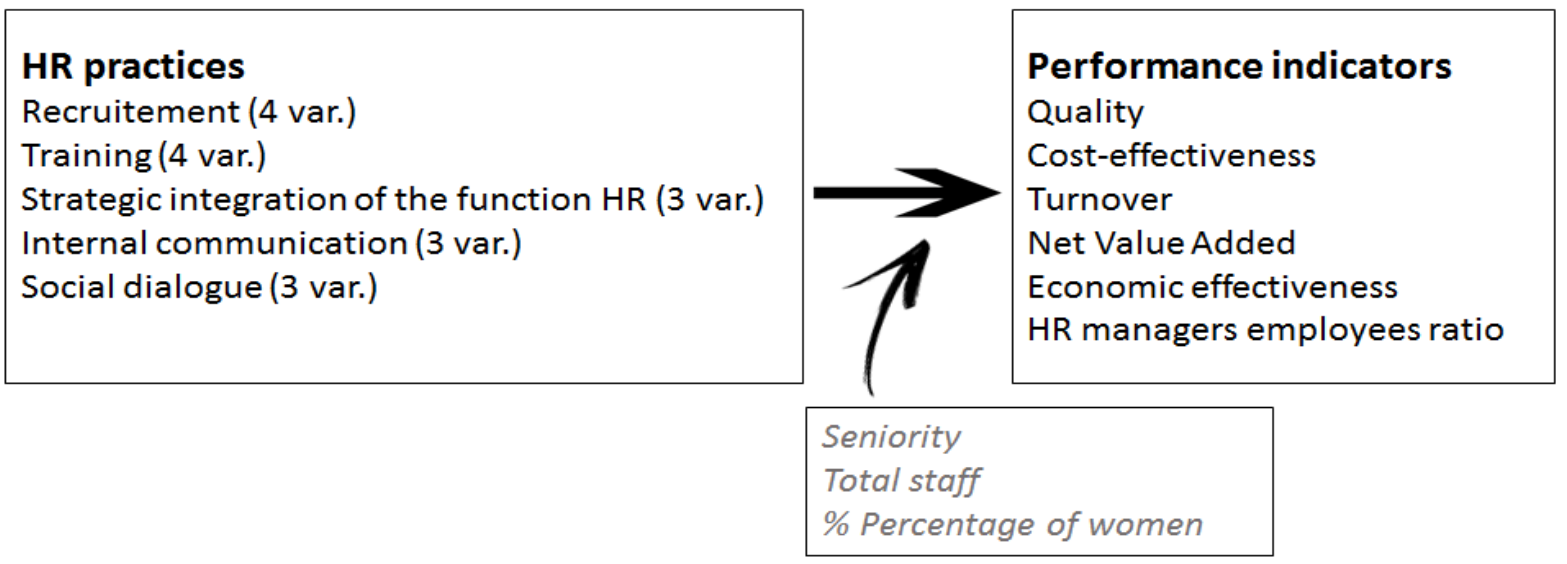

\section{Methodology}

The Structure Sample: This study was carried out from a study involving 92 large Moroccan firms (average size = 1530) representing the major industries in Morocco (Figure 2). A questionnaire was sent to those responsible for HRM 120 companies, the majority are included among the 500 largest companies in Morocco. Of these, 92 agreed to participate in the survey. Is a $80 \%$ response rate. During the preliminary phase of design work, a series of exchanges with professionals in the field was also conducted to assess there levanceof the questions. Our sample is represented primarily by national 
companies (62\%) of which $33 \%$ is publicly traded. The surveyed managers are a seniority level and study that allows them to be aware of the challenge similar studies and the importance of providing reliable information. Each company is autonomous in its management, some have relative autonomy given their attachment to parent companies. We also asked companies for their award-winning HR practices at the national or international level. This is particularly the case of Microsoft and the Mamounia. Our sample includes the oldest companies in Morocco as Cosumar, OCP Group, the Board of tobacco (Altadis) and BMCI (a subsidiary of BNP Paris below).

\section{Figure 1: Structure of the Sample N=92}
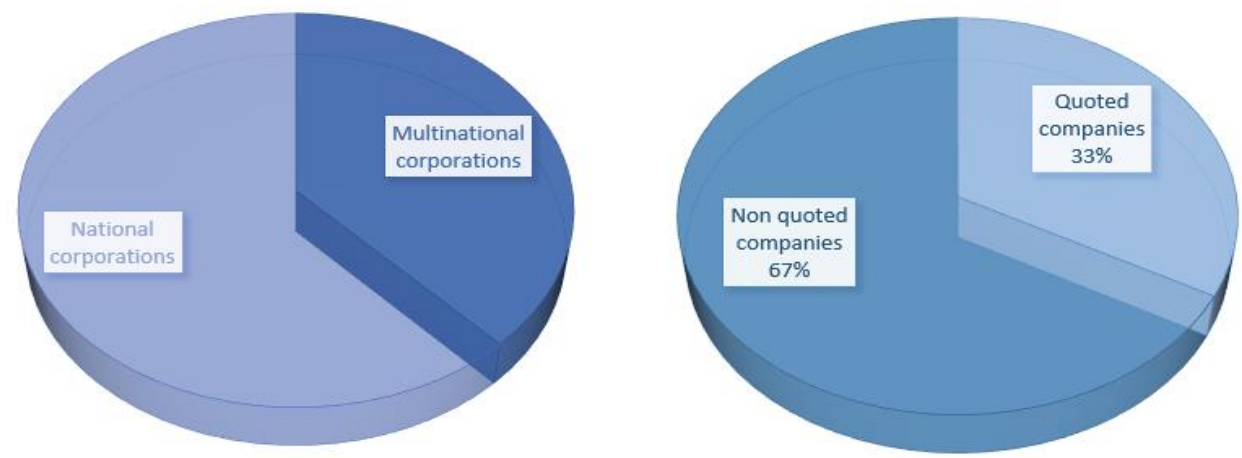

The Choice of Variables: Although there are several studies in the scientific literature, offering a variety of HRM practices, we still chose to validate the choice of these practices by some HR professionals. An approach that is the basis of extensive research (Arcand, 2000). Unnecessary or irrelevant practice was abolished. We chose 05 HRM practices declined in 17 variables. Questions are dichotomous or multiple choice types (Table 1). Performance in turn, is a multidimensional concept after extensive literature review. According Aît Razouk and Bayad, (2011) indicators predominate in the performance measurement were still financial and accounting. To remedy this, Bayad and Liouville, (1998) distinguished three types of indicators represented by a social dimension measured by performance, working time, absenteeism, etc., an organizational dimension measured by productivity, innovation and quality and finally an economic dimension represented by financial profitability indicators, trade and economic and sometimes even on the customer loyalty.

Other authors such as Dyer and Reeves, (1995) presented four types of results: social, organizational, financial and commercial. With that, we adopt a multidimensional measure of performance represented by three dimensions: economic, financial and commercial companies in the sample. The indicators measure the changing Turnover (CA), the quality, the value added (VA), the financial profitability (ROE) and the global teacher ratio approached by the formula Number of Frames / number of employees. We also study the impact of HR practices on performance perceived by managers represented by the quality and cost effectiveness. Some authors believe that a significant relationship between HRM practices and performance could result from subjective responses of surveyed HR managers. According Bayad and Aît Razouk, M. Bayad, (2011) managers involved in investigations usually have in mind an abundance of HRM practices implies better performance. To overcome this limitation, we also based on indicators from the summary statements of the period 2011-2012.

\section{Results}

Given the large number of quantitative dependent variables and categorical predictors we conducted an analysis by linear regressions. A statistical method that combines technical analysis of variance and regression to identify interactions between different types of variables. A first reading of the results (Table 2 Matrix of correlations) can observe the existence of a significant relationship between certain HR practices and performance indicators. We believe that the development of practices and the scope of their application may depend on the age or size. With that, the big companies would be sufficiently developed more concerned with the development of new practices so that smaller and younger would not necessarily a complex structure sufficiently to justify the development of certain practices. The statistics actually show that the 
introduction of certain practices varies depending on the number of employees. The correlation matrix shows that this recruitment practices $(r=0.313$, sig $=0.002)$, strategic integration of the HR function $(r=0.267$, sig = 0.010 ). And conversely, practices related to internal communication and social dialogue is less developed in companies with more women than men $(r=-0.208$, sig $=0.047 ; r=-0.291$, sig $=0.067)$.Seniority in turn reinforces the presence and development of social dialogue practices associated $(r=0.304$, sig $=0.003)$.

Effects Value Added (Va): Our statistics show that the VA seems to be related to a developed recruitment policy managed on a HRIS, favoring internal movement of all categories of staff and uses sources of candidates that are multiples $(\mathrm{R} 2=0.064$; sig $=0.015)$.

Table 1

\section{Recruitement}

Recruitement is managed in a Human Resource Service Management (HRMS)

Recruitment policy favors promoting from whithin for executives

Recruitment policy favors promoting from whithin for technicians and supervisors

Sources of recruitment are multiple

Training

The training policy préviligie specialized agencies

Training is managed in a Human Resource Service Management (HRMS)

Human resource planning anticipate needs whith training

The number of days of training

\section{Strategic integration of the function $H R$}

The presence of an entity of human resources management

The human resources manager is associated in the strategic decision-making

The management policy of the human resources is formalized and communicated to the employees

Internal communication

Written communication is important

Emailing is an important communications tool

The working meetings are an important communications tool

\section{Social dialogue}

The percentage of the unionized employees

Unions are important actors in collective bargaining

Unions influence decision-making

Effects Financial Profitability (Roe): The financial performance of the company, we have chosen to represent the ROE, appears to be significantly related to certain HR practices. Linear regression models show that this indicator is influenced by the presence of a formalized HR policy and communicated to employees $(\mathrm{R} 2=0.063 ; \mathrm{sig}=0.016)$ and the recruitment policy $(\mathrm{R} 2=0.050 ;$ sig $=0.033)$. The ROE seems to be also related to internal communication practices, particularly those associated with the use of written, e-mails and team meetings $(\mathrm{R} 2=0.058$; $\mathrm{sig}=0.021)$.

Effects on Perceived Quality by Hr Managers: We read on our models the presence of plausible links between the level of quality perceived by managers and certain HR practices associated with internal communication $(\mathrm{R} 2=0.045$; sig $=0.043$ ).

Effects Profitability Perceived by Hr Managers: As for the latter performance indicator, some HR variables related to social dialogue seems to have a predictive power variability $(\mathrm{R} 2=0.075$; $\mathrm{sig}=0.008)$. This is especially for social dialogue practices that made the partner unions in decision making.

Effects on the overall student ratio (Number of Frames / global workforce): Our statistics show in the following that this indicator is inversely associated with social dialogue practices $(\mathrm{R} 2=-0.208$, sig $=0.046)$. 
Parallel to the regression analysis, we have ensured that there is no effect of multi collinearity between variables related to the dependent variables of the model. Already, we emphasize that the studied HRM practices are not all capable of influencing the same way the performance indicators (Table 3 Results of linear regression).

Training: we are surprised at the low impact of practices related to skills development. This provides us with an unexpected result given the large literature suggesting that training is one of the most influential. And leads us to assume that the "universal" nature of certain practices is relative and it is related to the context in which the business is located. One possible explanation for the insignificant effect of training practices seems to be provided by the study by Fabi, Lacoursière, Morin and Raymond (2010) conducted among 382 employees. These authors have shown that training in Québec companies is seen as one of the major tools that directly impact job satisfaction and commitment to the organization and indirectly on performance. Some authors Decock Good and George, (2003) in particular, believe that the impact of training is not easy to prove since it is often shifted in time.

Table 2

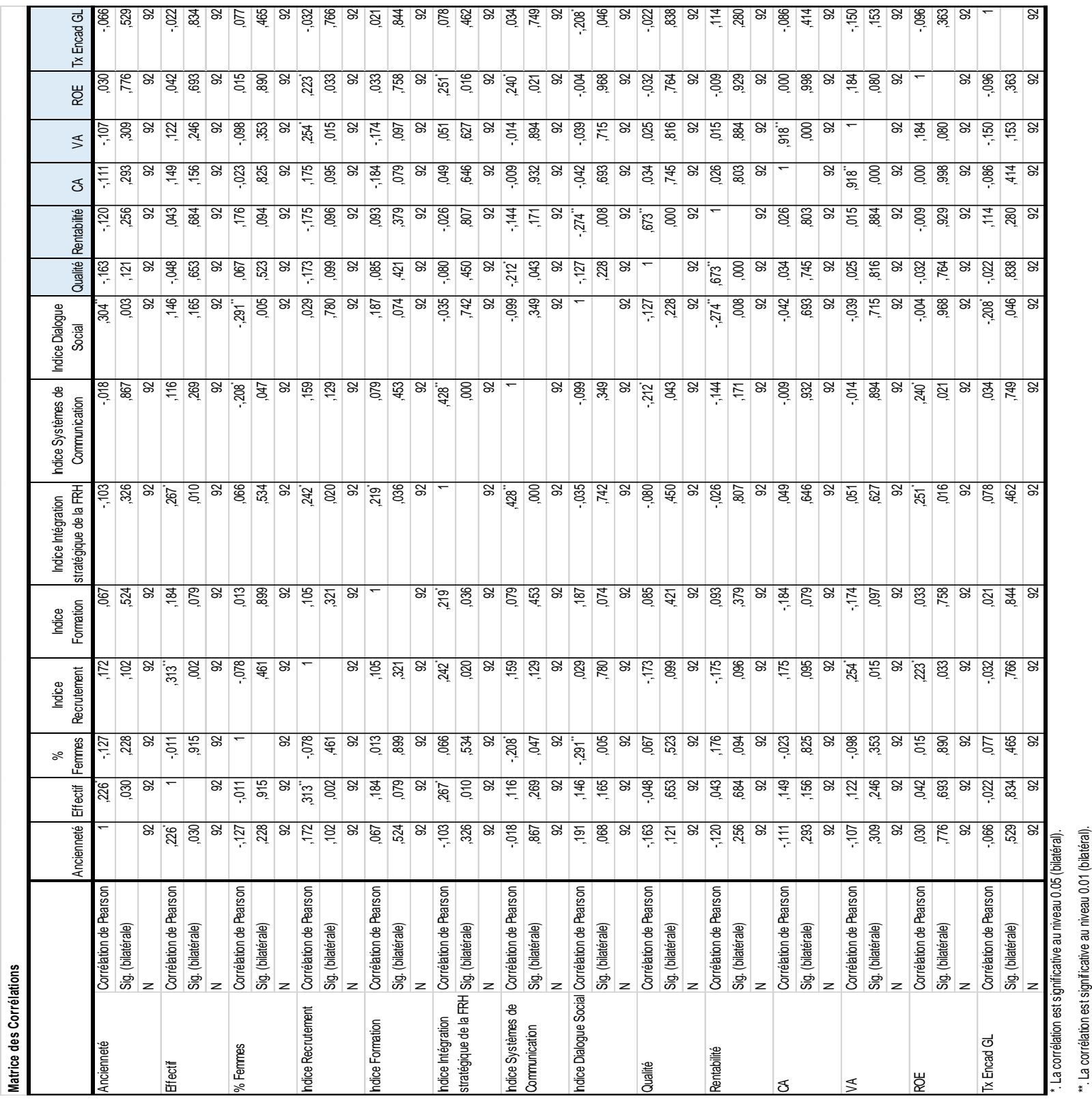


Table 2: Results of the Linear Regressions

\begin{tabular}{|c|c|c|c|c|c|c|c|c|c|c|c|c|}
\hline \multirow{2}{*}{ HR practices } & \multicolumn{2}{|c|}{ Quality } & \multicolumn{2}{|c|}{ Cost-effectiveness } & \multicolumn{2}{|c|}{ Turnover (CA) } & \multicolumn{2}{|c|}{ Value added (VA) } & \multicolumn{2}{|c|}{ Financial Profitability (ROE) } & \multicolumn{2}{|c|}{ Global Teacher Ratio } \\
\hline & R-deux & Sig. & R-deux & Sig. & R-deux & Sig. & R-deux & Sig. & R-deux & Sig. & R-deux & Sig. \\
\hline Recruitement & 0,300 & 0,990 & 0,310 & 0,960 & 0,310 & 0,950 & 0,640 & $0,015^{*}$ & 0,500 & $0,033^{*}$ & 0,001 & 0,766 \\
\hline Training & 0,007 & 0,421 & 0,009 & 0,379 & 0,034 & 0,079 & 0,030 & 0,097 & 0,001 & 0,758 & 0,000 & 0,844 \\
\hline Strategic integration of the function HR & 0,006 & 0,450 & 0,001 & 0,807 & 0,002 & 0,646 & 0,003 & 0,627 & 0,063 & $0,016^{*}$ & 0,006 & 0,462 \\
\hline Internal communication & 0,045 & $0,043^{*}$ & 0,021 & 0,171 & 0,000 & 0,932 & 0,000 & 0,894 & 0,058 & $0,021^{*}$ & 0,001 & 0,749 \\
\hline Social dialogue & 0,016 & 0,228 & 0,075 & $0,008^{* *}$ & 0,002 & 0,693 & 0,001 & 0,715 & 0,000 & 0,968 & 0,043 & $0,046^{*}$ \\
\hline
\end{tabular}

Discussion: No doubt such results are a real support for the Universalist theory of HR. However, can you confirm, as these analyzes, we were able to validate the supposed link exist between HRM practices and performance across the Universalist approach? Indeed, the statistics obtained from the returns of Moroccan companies show that this approach is relevant in social sciences. Some HR practices seem to be powerful on the principles of universalism. Topping the list, just those associated with internal communication, recruitment and strategic integration of the HRF. This result is not surprising according to the interviewed managers.

Recruitment: The significant effect of the recruitment practice in the variability of the VA and ROE is not surprising given the large number of studies that have placed him among the high-performance HRM practices. A result that is contrary to the conclusion of Arcand, (2000) on the lack of effect of staffing practices on the performance of DesJardins funds. Huselid, (1995) by cons set the selection of personnel among the most influential components on productivity and financial performance. The significant impact of recruitment practices that emphasize internal mobility of executives and technicians and supervisors on performance indicators is a result that was confirmed by some authors as DG Cabaret, (2009). The author's starting point was the hypothesis that the skills and competencies not used by the employee in a workstation could develop in the year and change to other activities and that the notion of potential competence refers to an evolving and dynamic design. The author suggests that internal mobility allows employees to develop their capacity for change. This is a practice that also reduces the costs of adaptation and prepare solutions to unforeseen future. In another study by Fabi, Raymond, Lacoursière and Arcand, (2004) among 200 SMEs, the authors confirmed the positive effect of this practice on the same performance if it is associated with a decrease in productivity in results. They explain that this decline is recoverable at other levels given the observed positive links with the rest of the performance indicators. This is particularly the gains made in the capacity of employee retention, development of new products and the evolution of the rate of return.

Internal Communication: Several research on the relevance of the RH-performance link placed internal communication and information dissemination among the most influential practices. The study by Gagnon and Arcand, (2011) in a Quebec manufacturing company (over 600 employees) corroborates our results. The authors concluded that the lack of planning and lack of information sharing on the vision cause deficiencies in the definition of objectives. These shortcomings result in lower performance. A second study was conducted by Benedict and Rousseau, (1990) with 21 private sector SMEs in Quebec. The results of the study have placed internal communication among the best performing HRM practices. However, some authors such as B. Fabi, R. Lacoursière, L. Raymond et J. St-Pierre (2010) estimate that the practice effect in question is favorable, but it is visible on the term job satisfaction and employee engagement. An additional explanation appears in the results of the longitudinal study by Aît Razouk and Bayad (2011) to understand the relationship between HR practices and performance. The authors concluded that internal communication and dissemination of information on the company's strategy and organizational goals are among the most effective HR practices but whose effect is shifted in time.

According to A. Ait Razouk, (2014) practices of participation and sharing of information allow employees to feel a part of decision-making and also understand the meaning of their commitment to the organization. Bryson, (1999) meanwhile, concludes that some HR practices associated with communication, participation and compensation have a significant impact on the variability of financial performance as they are applied in 
SMEs or large structures of more than 200 employees. His study involved a sample of 178 SMEs and 386 large companies. In some Moroccan businesses, access to information on new strategic directions is still limited to an elite. In these organizational contexts, only the managers and employees "appreciated" by their hierarchies are informed. The withholding of information is exercised even between vis-à-vis managers of a new employee or following organizational changes. The spread of information and sharing of vision and financial performance with all employees represent a major paradigm shift in several companies in Morocco.We continue to see in companies that attendance at meetings on new projects or new strategic directions is not accessible to everyone.

The Strategic Integration of the Hrf: Indeed, the results obtained by Bruno, Lacoursière, Martin and Raymond, (2010) on the most effective HR practices for retention and engagement of employees joining our conclusion. These authors identified 10 practices that may have a positive effect on job satisfaction, commitment to the organization and employee retention. This leads to an improved product quality, improved productivity and profitability. They concluded that the activities under the theme "Communication and Participation" for employees to be informed regularly about the objectives of the organization and the organization of work are among the trio of the most influential practices satisfaction work. Definitely, it seems clear that in the Moroccan context, the integration of social concern in the development of HR practices is linked to the respect of legal texts (DIORH, 2012). Despite this, some companies are developing new practices that go beyond what is required by the labor code in order to be more competitive. They often draw successful practices of multinationals. A similar conclusion on the French context was made by Coulon, (2006) in a study involving 106 HR professionals. The author claims that French companies are not developing original practices but rather are required by law. The rest of the practices developed to improve their competitiveness.

Social Dialogue: While it is clear that the importance of social dialogue in a structure shows a strong presence of unionized staff, it stands to follow that it is a practice generally represented by employees of a certain age. Indeed, authors like De Coster, A. Cornet and C. Delhaye, (1999) explain that it is important to make the distinction between movements fighting for change for workers and the presence of organized unions explain to the workers the decisions of power and exercise oversight or supervision missions. Hence the link between the practice and the indicator measuring the overall supervision. We believe that these practices are complementary and substitutable and are able to reduce managerial efforts in the company.

\section{Conclusion}

Overall, the results obtained from tests support our Universalist assumption. The positive and significant correlations presented the scope of several HRM practices with certain performance indicators advocate this perspective that some HR practices have a positive effect on performance each time they are applied. Without a doubt such results are a real support for the Universalist theory of HR is the perspective that until now have relied more research. Some authors, Becker and Gerhart, (1996) in particular, argue that there is no magic formula regarding HR practices to implement for better efficiency. However, can you confirm, as these analyzes, we were able to validate the supposed link exist between HRM practices and performance? It appears that in our sample companies, some HR practices are able to develop some performance indicators. HR professionals have every incentive to invest in the development of HRM system using these practices called "winning." Our study brings additional insight to the question on the RH-performance link in Moroccan companies which represent a field of research that is relatively young and worth exploring further. However, all research has limits, and ours is no escape from this principle. In order to explain the scope of other practices, authors like Mr. Arcand, (2000) proposes to introduce the culture of the organization to be considered in this kind of analysis. It should be added that in addition to the limit associated with universalism, our study was cross- sectional. Roll out the study over several years is in our opinion, an extension of great significance in order to give more meaning to the links posted by statistical models. Also, it should be stressedthat the modelsassociated withuniversalismare simplistic (Lacoursière, Fabi, St-Pierre Arcand, 2005) and ignoreinteractions withcontingency factorsinside andoutsidethe company. As suggested by theaut hors of universalism, these studies areto be completed byothersthat take into accountinteractionswith the environment. 


\section{References}

Ayache, A. (1957). Les greves de juin 1936 au Maroc, dans les Annales : Economies, Societes, Civilisations, 12e annee, 3, 418-429.

Aït Razouk, A. (2014). Mobilisation des ressources humaines et innovation des PME, Analyse longitudinale sur des données françaises, Revue française de gestion, 243, 107-126.

Aït Razouk, A. \& Bayad, M. (2011). GRH mobilisatrice et performance des PME, Revue de gestion des ressources humaines, 4(82), 3-18.

Aït Razouk, A. \& Bayad M. (2011). GRH mobilisatrice et performance des PME, Revue de gestion des ressources humaines, 82, 3-18.

Allani-Soltan, N., Bayad, M. \& Arcand, M. (2003). Impact de la gestion stratégique des ressources humaines sur l'innovation, Acte du congrès de l'Association francophone de la gestion des ressources humaines, Grenoble.

Allani-Soltan, N., Bayad, M. \& Arcand, M. (2004). Etude de l'efficacité de la grh des entreprises françaises : l'approche configurationnelle, in Actes du Congrès de l'agrh, 2004 1-4 septembre, Montreal, 1-30.

Arcand, M. (2000). Leffet des pratiques de gestion des ressources humaines sur l'efficacité des caisses Populaires Desjardins du Québec, Thèse de doctorat, Université de Metz, 267.

Barney, J. (1991). Firm resources and sustained competitive advantage, Journal of Management, 17(1), 99-120.

Barrette, J. \& Ouellette, R. (1997). Gestion de la performance : impact sur la performance organisationnelle de l'intégration de la stratégie et de la cohérence des systèmes de GRH, Relations industrielles / Industrial Relations, 55(2), 207-226.

Barrette, J. \& Simeus, M. (1997). Pratiques de gestion des ressources humaines et performance organisationnelle dans les entreprises de haute technologie, Actes du congrès annuel de la section Ressources humaines de l'Association des sciences administratives du Canada, 18(9).

Bayad, M. (1997). Revue internationale P.M.E. : économie et gestion de la petite et moyenne entreprise, 10(3-4), 57-80.

Becker, B. Gerhart, B. (1996). The impact of human resource management on organizational performance: Progress and prospects, Academic of Management Journal, 39, 779-801.

Becker, G. (1962). Investment in human capital: a theoretical analysis, Journal of Political Economy, 70, 9-49.

Benoît, C. \& Rousseau, M. D. (1990). La gestion des ressources humaines dans les petites et moyennes entreprises au Québec», Revue internationale P.M.E. : economie et gestion de la petite et moyenne entreprise, 3(1), 39-55.

Bourguignon, A. (1995). Peut-on définir la performance? Revue française de comptabilité, Juillet-Août, 269, 6165.

Brouwers, I. \& Cornet, A. (1997). Management humain et contexte de changement: Pour une approche constructive, De Boeck Supérieur, 7-8.

Cabaret, D. G. (2009). Gestion de la mobilité, un acte managérial à part entière, European Journal of Social Law (Revue Européenne du Droit Social), Issue: 6-19.

Chênevert D., Sire B. \& Tremblay M. (1998). Une étude internationale sur la contingence de l'efficacité perçue des politiques de rémunération", Actes du 9ème Congrès de l'AGRH, Université de Saint-Quentin en Yvelines, 351-367.

Chrétien, L., Arcand, G., Tellier, G. \& Arcand, M. (2005). Impacts des pratiques de GRH sur la performance organisationnelle des entreprises de gestion de projets, Revue internationale sur le travail et la société, 3(1), 78-95.

Decock Good, C. \& Georges, L. (2003). Gestion des ressources humaines et performance économique: une étude du bilan social?, Comptabilité - Contrôle - Audit, 9, 151-170.

De Coster, M., Cornet, A. \& Delhaye, C. (1999). Sociologie du travail et gestion des ressources humaines, De Boeck Université, 111-112.

Delery, J. \& Doty, H. (1996). Modes of theorizing in strategic human resource management: tests of universalistic, contingency and configurational performance predictions, Academy of Management 
Journal, 39(4), 802-835.

DIORH, (2012). Results of the survey launched each year by an HRM consulting firm called Diorh, Edition.

Dyer, L. \& Reeves T. (1995). HR Strategies and firm Performance: What do We Know and Where do We Need to Go?, International Journal of Human Resource Management, 6, 656-670.

Emery, Y. (2003). Renouveler la gestion des ressources humaines, PPUR Presses polytechniques, 30.

Fabi, B. \& Lacoursière R. (2005). Risque de pénurie : les PME sont-elles en mesure de fidéliser leurs ressources humaines ?", Actes du colloque, 11e Journées scientifiques du Réseau Entrepreneuriat, Trois-Rivières, Québec, Canada.

Fabi B., Lacoursière, R., Raymond L. \& St-Pierre, J. (2010). Capacités de GRH et productivité des PME industrielles: une perspective contingente, Management \& Avenir, 9(39), 110-123.

Frimousse, S. \& Peretti, J. M. (2005). Apprentissage stratégique des pratiques de GRH, internationalisation des firmes et espace euro-maghrébin, Management \& Avenir, 3(5), 45-61.

Gagnon, O. \& Arcand, G. (2004). Les pratiques de GRH comme catalyseur de la performance organisationnelle, Revue internationale sur le travail et la société, 9(2), 1-23.

Guérin, G. \& Wils, T. (2002). La gestion stratégique des ressources humaines, HEC Montréal, Gestion, 27, 24-23.

Huselid, M. A. (1995). The impact of Human Resource Management Practices on Turnover, Productivity and Corporate Financial Performance, Academy of Management Journal, 38(4), 949-969.

Lacoursière, R., Fabi, B., ST-Pierre, J. \& Arcand, M. (2004). Communication présentée au Congrès de l'Association de gestion des ressources humaines (AGRH), tenu à Montréal, 1er au 4 Septembre 2004, Impacts de la GRH sur différents indicateurs de performance : résultats d'une étude empirique en contexte de PME manufacturières, 1-3.

Liouville, J. \& Bayad, M. (1998). Human Resource Management and Performances. Proposition and Test of a Causal Model, Zeitschrift fûr Personal forschung, 3, 337-52.

McMahan, G., Virik, M. \& Wright, P. M. (1999). Theoritical Perspectives for SHRM, Research in Personnel and Human Resources Management, Sup. 4, 99-122.

Oved, G. (1961). Problèmes du développement économique au Maroc, Tiers-Monde, tome, 2(7), 355-398.

Schultz, T. W. (1961). Investment in Human Capital, The American Economic Review, 51(1), 1-17.

Weiss, D. (1979). Relations industrielles et développement des organisations, Revue d'économie industrielle. Aspects humains et sociaux de l'économie industrielle, 10, 79-93.

Zimmermann, M. (1914). la population du Maroc. L’essor économique, 1914, Annales de Géographie, 23 (129), 281-284. 